\title{
Trials to improve the colour of colour fixed cottonseed oil using sodium oleate and sodium stearate in the absence and presence of azeotropic extract of cottonseed meal
}

\author{
By Elham A. A. Yousef \\ National Research Centre, Giza, Egypt.
}

\section{RESUMEN}

Ensayos para mejorar el color del aceite de semilla de algodón con color fijado usando oleato sódico y estearato sódico en ausencia y presencia de extracto azeotrópico de harina de semilla de algodón.

Se estudió la eficacia de dos aditivos, a saber, oleato sódico y estearato sódico preparados en laboratorio para mejorar el color del aceite de semilla de algodón con color fijado. También se tuvo en consideración la presencia de extracto azeotrópico de harina de semilla de algodón junto con oleato sódico al $50 \%$ o estearato sódico al $10 \%$. Se observó la mejora en el índice de color de la mayoría de las muestras de aceite decolorado y refinado tratado. Esto está confirmado con la reducción de los contenidos en gosipol de las muestras de aceites refinados y decolorados tratados comparado con la muestra de aceite no tratado.

PALABRAS-CLAVE: Aceite de semilla de algodón - Color Estearato sódico - Extracto azeotrópico de harina de semilla de algodón - Oleato sódico.

\section{SUMMARY}

Trials to improve the colour of colour fixed cottonseed oil using sodium oleate and sodium stearate in the absence and presence of azeotropic extract of cottonseed meal.

The effectiveness of two additives, namely, laboratory prepared sodium oleate and sodium stearate to improve the colour of colour fixed cottonseed oil was studied. Also the presence of the azeotropic extract of cottonseed meal together with $5 \% \mathrm{Na}$ oleate or $10 \% \mathrm{Na}$ stearate was taken in consideration. Improvement in the colour index of most treated refined and bleached oil samples is observed. This is confirmed with the reduction of gossypol contents of the refined and bleached treated oil samples compared with the untreated oil sample.

KEY-WORDS: Azeotropic extract of cotton seed meal - Colour - Cottonseed oil - Sodium oleate - Sodium stearate.

\section{INTRODUCTION}

Wherever cottonseed oil is marketed, colour is considered a gauge of its quality. Colour causing pigments are removed from vegetable oils during the refining and bleaching operations. In conventional methods of refining, aqueous alkali of proper strength and in proper proportions is used. In cottonseed oil, native gossypol (a poly phenolic binaphthaldehyde) is the principal colour-causing pigment. Gossypol is alkali soluble and should be removed on alkali refining. However under improper conditions of storing and processing, gossypol undergoes some changes which affects its acidic character, and is therefore not removed from the oil by conventional refining. Such oil is called «colour fixed" (1-3).

Three major approaches are reported (4) on the prevention of colour-fixation and the treatment of colour-fixed oil. These include: 1 - modification of the conventional refining process through the use of excess alkali, alcoholic-alkali or carrying out multistage refining, 2- using additives to remove gossypol and/or colour-fixed pigments, 3- adsorption of pigments on suitable sorbent.

The present work has been designed to study the effectiveness of two additives namely, laboratory prepared sodium oleate and sodium stearate to improve the colour of colour fixed cottonseed oil.

The two additives in two percentages, namely, 5 and 10 were added to the crude oil in two forms: a- powder and b-alcoholic solution (the additive is dissolved in a minimun amount of $90 \%$ ethanol).

The effectiveness of sodium oleate $5 \%$ and sodium stearate $10 \%$ on the azeotropic extract of cottonseed meal on the fixation of cottonseed oil is also taken in consideration during our study.

\section{MATERIALS AND METHOD}

\section{1.- Crude Cottonseed Oil}

Cottonseed Giza 80 (Gossypium barbadense) used in the present study was supplied by the Cotton Research Institute of the Ministry of Agriculture.

The cottonseed oil was completely extracted:with commercial hexane in a soxhelt apparatus. The oil was desolventized in a rotary evaporator under vaccum at $45^{\circ} \mathrm{C}$.

Crude oil was kept in closed bottels in a refrigerator. 


\section{2.- Additives:}

a.- Sodium oleate (I) and sodium stearate (II) were used as additives. They were prepared by saponification of both oleic and stearic acids (Merk) with sodium hydroxide.

b.- Azeotropic extract of the cottonseed meal (III)

Defatted cottonseed meal was extracted by acetone: hexane: water (53:44:3) mixture. The dried azeotropic extract was added in 4\% W/W to the crude cottonseed oil.

\section{Procedure}

\section{1.- Colour Fixation}

Eight samples of the crude cottonseed oil containing the additives were subjected to colour fixation at $60^{\circ} \mathrm{C}$ for a period of 15 days as described by Pons et al (5) and recommended by Atteia et al. (6)

The samples are as followes:

[A5] Oil with $5 \%$ sodium oleate, powder.

[A10] Oil with $10 \%$ sodium oleate, powder.

[B5] Oil with $5 \%$ sodium oleate, solution.

[B10] Oil with $10 \%$ sodium oleate, solution.

[C5] Oil with $5 \%$ sodium stearate, powder.

[C10] Oil with $10 \%$ sodium stearate, powder.

[D5] Oil with $5 \%$ sodium stearate, solution.

[D10] Oil with $10 \%$ sodium stearate, solution.

[G] Crude cottonseed oil, as control.

Another three oil samples of crude cottonseed oil with $4 \% \mathrm{~W} / \mathrm{W}$ azeotropic extract III were subjected , colour fixation as above but the additives were as followes:

[E] Oil with III $+5 \%$ I (Na-oleate), solution.

[F] Oil with III $+10 \%$ II (Na-stearate), powder.

[G*] Oil with III only as control.

The last three samples with the mentioned additives were selected according to the results obtained from the eight samples subjected to colour fixation. These selected samples gave the condition to obtain the best colour after refining and bleaching.

\section{2.- Analysis}

At the end of the colour fixation process the oil samples were subjected to centrifugation to obtain clear oils. Refining then bleaching were carried out on the clear oil samples according the procedure described by official method in the A.O.C.S. (7) for the cottonseed oil. In case of refining, calculated amount of sodium hydroxide solution (8) was added based on the percentage of free fatty acids. Refining was carried out with stirring at $60^{\circ} \mathrm{C}$. for 30 minutes. In 'case of bleaching, bleaching earth «Tonsil» was used at $110^{\circ} \mathrm{C}$ with stirring for 10 minutes.

The free fatty acid of all treated oil samples were determined according to the A.O.C.S. method (7).

The spectrophotometric analysis $(2,3,6)$ of the treated crude oils, refined and bleached oils was carried by using Shimedzu U.V. visible Recording Spectrophotometer, model UV 240 Graphcord. Wavelength range from 300 to $700 \mathrm{~nm}$ was used. The oil samples were diluted with $\mathrm{CCl}_{4}$ at the ratio of $1: 25$ by volume for crude oil, and at the ratio of $1: 10$ by volume for refined and bleached oils. The colour index was identified by calculating the area under the absorption spectra in the region $400-550 \mathrm{~nm}(1,9)$.

\section{RESULTS AND DISCUSSION}

The well know problem of darkening of crude cottonseed oil has been generally known as "Colour Fixation". This problem has been accentuated because of difficulties in removing the fixed pigments from the off-coloured oils by current methods of alkali refining and bleaching (10). It is decided from several observations is that the major colouration in cottonseed oil owes its origin to gossypol, the principal pigment of mature cottonseed. The concentration of gossypol, or perhaps gossypol derivatives in crude cottonseed oil are responsible for the colour fixation problem (11).

The present study was designed to investigate the effect of additives, namely, sodium oleate and sodium stearate in powder and solution forms also in two concentrations, namely, $5 \%$ and $10 \%$ during colour fixation process. Also, the effect of adding azeotropic extract of cotonseed meal to the crude oil in the presence of specific additives (5\% Na oleate in solution and $5 \% \mathrm{Na}$ stearate in powder) was also investigated.

\section{1.- Effect of Addition of $\mathrm{Na}$ Stearate as well as $\mathrm{Na}$ oleate in Powder and in Solution Form on Colour Fixation of Crude Cottonseed Oil.}

The Figures 1-3 represent, the spectrophotometric analysis of the fixed crude oil samples $A, B, C, D$ (Figures 1a \& 2a); after refining (Figures $1 b$ \& $2 b$ ) and after bleaching (Figures 1c-2c); For comparison the control sample, $G$ which is the fixed oil without additives is included. 

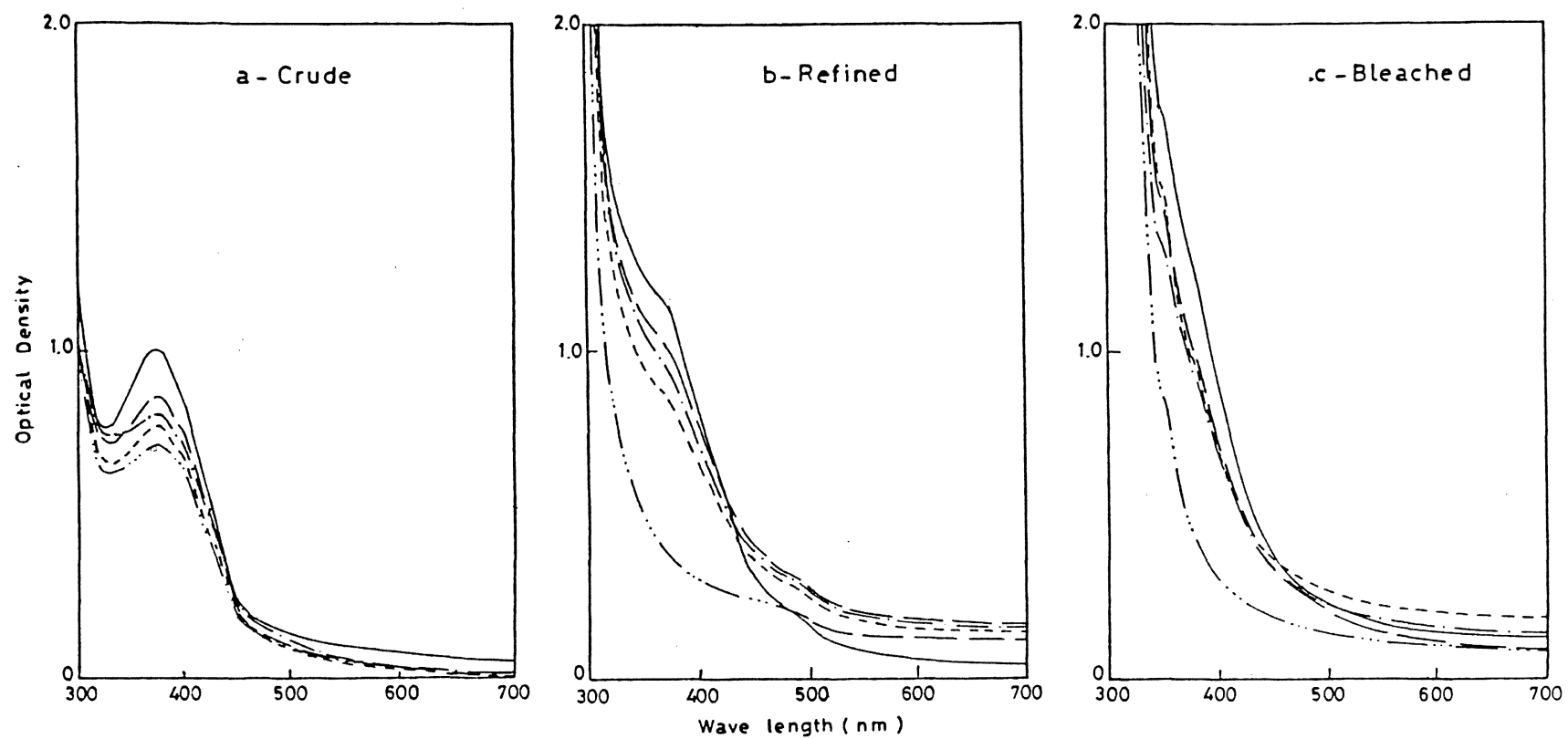

Figure 1

Absorption Spectra of "Fixed" Cottonseed Oil (CSO) Samples with Additives in Powder.

\section{CSO (Control)}

.... CSO $+5 \%$ Na Oleate

-- CSO $+10 \%$ Na Oleate

- $\mathrm{CSO}+5 \% \mathrm{Na}$ Stearate

$-\ldots-\mathrm{CSO}+10 \% \mathrm{Na}$ Stearate
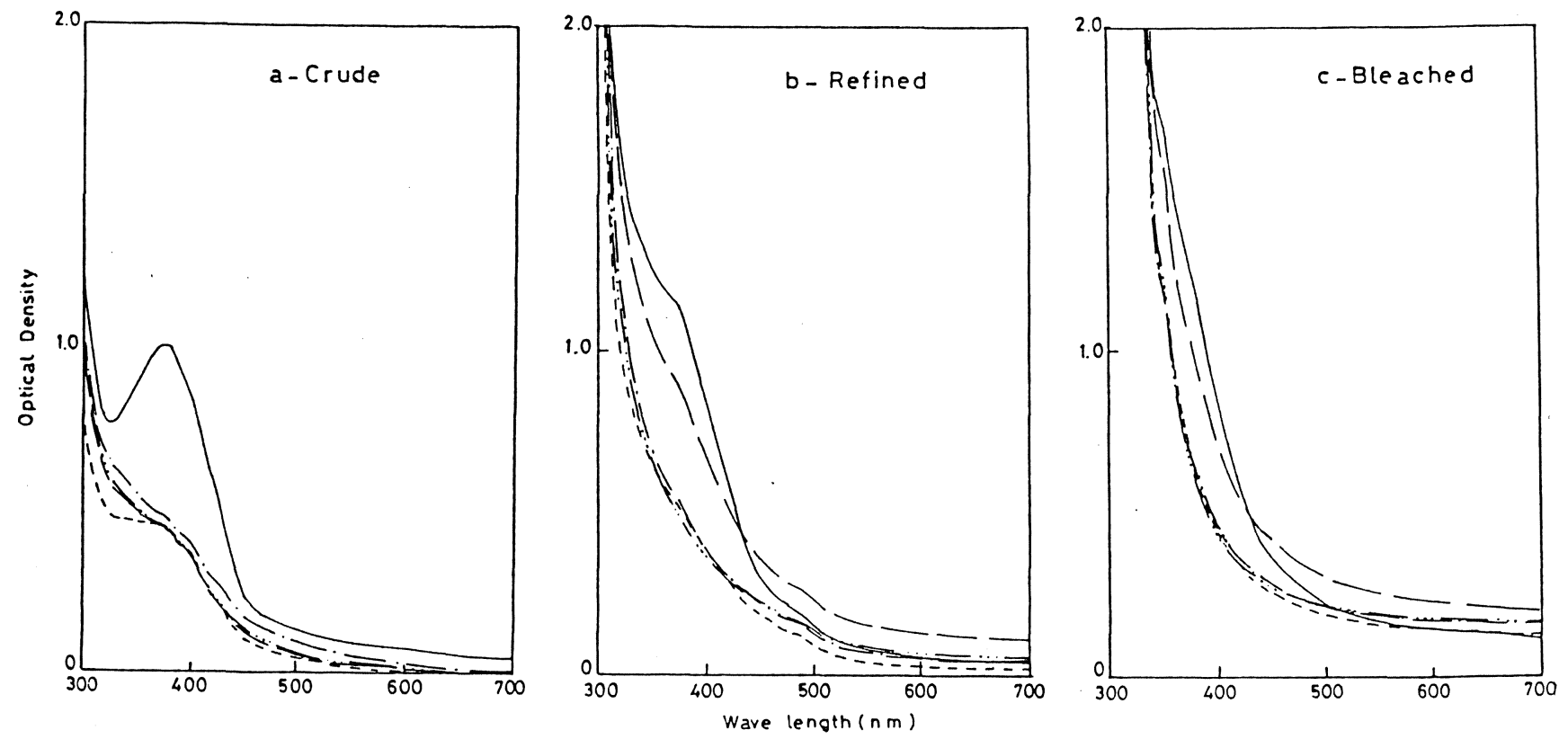

Figure 2

Absorption Spectra of "Fixed» Cottonseed Oil (CSO) Samples with Additives Solution.

\section{CSO (Control) $\quad$.... CSO $+5 \%$ Na Oleate}

- - CSO $+10 \%$ Na Oleate

- $\mathrm{CSO}+5 \% \mathrm{Na}$ Stearate $\quad-\ldots-\mathrm{CSO}+10 \% \mathrm{Na}$ Stearate 

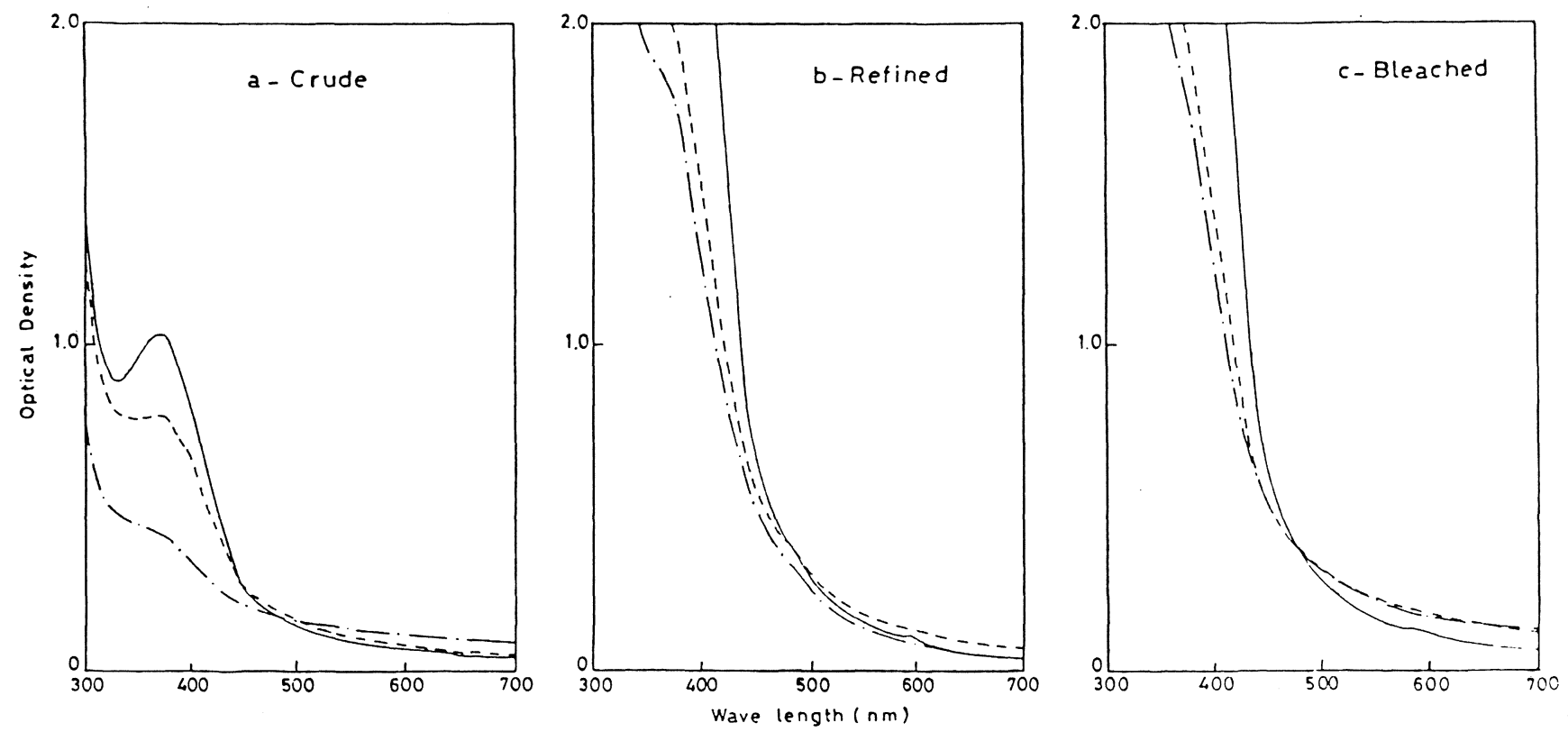

Figure 3

Absorption Spectra of «Fixed» Cottonseed Oil (CSO) + 4\% Azeotropic Extract (AE). CSO $+\mathrm{AE}$ (Control) $\quad . .-\mathrm{CSO}+\mathrm{AE}+5 \% \mathrm{Na}$ Oleate (in Solution). - $\mathrm{CSO}+\mathrm{AE}+10 \% \mathrm{Na}$ Stearate (in Powder).

Figures 1a \& 2a show high decrease in the optical densities of the absorption spectra of all fixed crude cottonseed oil samples in the following order:

a.- Additives in solution: [B5]>[D5] and [D10]>[B10],

b.- Additives in powder. [C10]>[A5]>[A10]>[C5]>[G].

The colour index of the above mentioned samples were increased as shown in the given table as follows:

$17.9,20.3,21.0$, and $26.3,32.6,35.3,39.4,38.0$ and 44.7, for B5, D5, D10, B10; and C10, A5, A10, $\mathrm{C} 5$ and $\mathrm{G}$, respectively.

On the other hand the gossypol content of all treated crude oil samples are as follows as shown in the Table: $0.2,0.1,0.13,0.12,0.04,0.03,0.05,0.01$ and 0.2 for $\mathrm{A5}, \mathrm{A10}, \mathrm{C} 5, \mathrm{C} 10, \mathrm{~B} 5, \mathrm{~B} 10, \mathrm{D} 5, \mathrm{D} 10$, and G.

Figures $1 b \& 2 b$ give the absorption spectra of the fixed oil samples after refining. It shows a high decrease in the optical densities of the refined oil samples in the following order: $[\mathrm{B} 5]>[\mathrm{B} 10]>[\mathrm{D} 10]>[\mathrm{D} 5]$ (additives in solution). Although the absorption spectra of sample [D10] in the gossypol region is less than that of sample [B5] yet in general the colour index of sample [D10] is still high than that of sample [B5]. In case of additives in powder form, the absorption spectra are also in a decrease order as follows: $[\mathrm{C10}]>[\mathrm{A} 5]>[\mathrm{A10}]>[\mathrm{C} 5]>[\mathrm{G}]$ (additives in powder). This confirmed by the values given by the colour index and gossypol contents as given in the Table.
The absorption spectra of the bleached oil samples are given in Figures 1c-2c. At the same time also the colour index and the gossypol contents are represented in the Table.

The optical densities of the bleached oil samples as shown in the absorption spectra in Figure 3 a decrease simultaneously in the following order:

$B 5>B 10, D 10>D 5>G$ in case of additives in solution form. Whereas by using additives in powder form as in Figure $3 b$ the decrease of the optical densities are in the following order.

\section{$\mathrm{C} 10>\mathrm{C} 5$ \& $\mathrm{A} 10>\mathrm{A} 5>\mathrm{G}$.}

The decrease in the colour index of the bleached oil samples were given in the following sequence, $\mathrm{D} 5>\mathrm{A} 5>\mathrm{A} 10>\mathrm{C} 5>\mathrm{B} 10>\mathrm{D} 10>\mathrm{B} 5>\mathrm{C} 10$, beginning with 64.0 for the sample of the oil treated with $5 \%$ sodium stereate in solution and ended with 18.3 for the oil sample treated with $10 \%$ sodium stereate in powder; whereas the colour index of the fixed crude cottonseed oil without additives was 58.8 .

The gossypol contents range from zero (for the oil sample treated with $5 \%$ sodium stearate in powder) to 0.04 for the oil sample treated with $5 \%$ sodium stearate in solution. 
Table

Effect of Sodium Stearate as well as Sodium Oleate Addition on the Colour Characteristics of Crude Cottonseed Oil after Fixation

\begin{tabular}{|c|c|c|c|c|c|c|c|}
\hline \multirow{2}{*}{\multicolumn{2}{|c|}{ Treatment }} & \multicolumn{3}{|c|}{$\%$ Gossypol $^{*}$} & \multicolumn{3}{|c|}{ Colour index } \\
\hline & & C & $\mathbf{R}$ & B & C & $\mathbf{R}$ & B \\
\hline \multirow[t]{5}{*}{ 1.- } & Powder form & & & & & & \\
\hline & A5 & 0.200 & 0.080 & 0.006 & 35.300 & 53.900 & 55.900 \\
\hline & A10 & 0.100 & 0.050 & 0.010 & 39.400 & 58.200 & 51.400 \\
\hline & C5 & 0.130 & 0.006 & 0.000 & 38.000 & 61.800 & 49.600 \\
\hline & C10 & 0.120 & 0.010 & 0.010 & 32.600 & 33.200 & 18.300 \\
\hline \multirow[t]{6}{*}{ 2.- } & Solution form & & & & & & \\
\hline & B5 & 0.040 & 0.070 & 0.010 & 17.900 & 25.300 & 39.400 \\
\hline & B10 & 0.030 & 0.000 & 0.010 & 26.300 & 30.000 & 43.400 \\
\hline & D5 & 0.050 & 0.040 & 0.040 & 20.300 & 52.200 & 64.000 \\
\hline & D10 & 0.010 & 0.006 & 0.007 & 21.000 & 30.200 & 42.400 \\
\hline & G & 0.200 & 0.090 & 0.020 & 44.700 & 47.900 & 58.800 \\
\hline \multirow[t]{4}{*}{ 3.- } & Azeotropic Extract & & & & & & \\
\hline & $E$ & 0.030 & 0.030 & 0.000 & 42.200 & 87.200 & 84.300 \\
\hline & $F$ & 0.000 & 0.000 & 0.000 & 31.600 & 74.500 & 80.200 \\
\hline & $\mathrm{G}^{*}$ & 0.220 & 0.090 & 0.020 & 45.500 & 116.300 & 115.100 \\
\hline
\end{tabular}

C: Crude oil, R: Refined, B: Bleached.

It can be concluded from the overall results of the mentioned experiments that using additives like $\mathrm{Na}$ stearate as well as $\mathrm{Na}$ oleate in powder and in solution forms on the process of colour fixation of crude cottonseed oil will lead to the following comments:

a.- Improvement in the colour index of the treated refined and bleached oils over the untreated oil.

b. - The gossypol contents of refined and bleached oils were reduced compared with the untreated oil (control).

c.- The efficiency of these treatments is very clear from the overall results specially when using either $10 \% \mathrm{Na}$ stearate powder or $5 \% \mathrm{Na}$ oleate, solution and is in agreement with the finding of Paulose and Achaya (12), Taha et al (13) and Atteia (14). This efficiency may be probably due to the alkaline character of sodium stereate as well as sodium oleate.

\section{2.- Effect of Addition of Azeotropic Extract of Cottonseed Meal in Presence of Specific Additives of $5 \% \mathrm{Na}$ Oleate \& $\mathrm{Na}$ stereate on Colour Fixation of Crude Cottonseed Oil.}

From previous investigations, gossypol proved to be the responsible factor for colour fixation of cottonseed oil $(1,6,14)$. Colour fixation is more pronounced in the refined and bleached oil samples, also in the fixed refined and bleached oil samples containing gossypol. This is a further proof that gossypol is the main pigment that affects colour-fixation. The effect of gossypol on colour fixation is due to the existance of free carbonyl groups in gossypol. Gossypol is a polyhydroxyphenolic compound having two carbonyl groups that possess the property of forming compounds with many substances $(15-17)$. The reactive groups of gossypol are the two 
carbonyl groups and the six hydroxyl groups. The most biologically important reactions are the formation of bound gossypol (17).

Figures (3) represent the spectrophotometric analysis of the two samples of fixed oils containing the azeotropic extract of the cottonseed meal, in addition to $5 \%$ sodium oleate in solution for the one sample and $10 \%$ sodium stearate in powder for the second one, before and after refining and bleaching, together with a control sample with azeotropic extract $\left(\mathrm{G}^{*}\right)$ for comparison.

The highest decrease of the optical density of the absorption spectra as shown in Figure (3a) is for the crude fixed oil sample «F» (sample with azetropic extract with $10 \%$ sodium stearate in powder) followed by the second crude fixed oil sample "E» (sample with azeotropic extract).

Regarding the colour index of the fixed oils treated with the mentioned solution soaps in presence of the azeotropic extract, the lowest value 31.6 was for the fixed oil sample $F$ with $10 \%$ sodium stearate in powder whereas the highest value 42.2 was for the fixed oil sample $E$ with $5 \%$ sodium oleate in solution in comparison to the value without soap additive which was 45.5. The gossypol contents were 0.03 , zero, 0.22 for $E, F, G^{*}$, respectively.

The optical densities of the absorption spectra of the fixed oil samples treated with the sodium soaps in presence of azeotropic extract after refining and bleaching (Figure $3 b \& 3 c$ ) show high decrease compared with that of fixed oil samples treated only with azeotropic extract in absence of sodium soaps. These results are conformed with the values found as shown in the Table, the colour indexes: 74.5, 87.2 and 116.3; gossypol content: zero, $0.03,0.09$ for $F$, $E$, and $G^{*}$ respectively after refining whereas colour indexes were 80.2, 84.3, 115.1; gossypol contents were: zero, zero, 0.02 for $F, E$, and $G^{*}$ respectively after bleaching.

It can be thus concluded from the overall results of these experiments that the addition of $4 \%$ azeotropic extract of cottonseed meal to crude cottonseed oil which was then subjected to colour-fixation leads to the following results:

- Decrease in the colour index of the treated refined and bleached oils than the untreated oil.

- This is confirmed by the reduction of the gossypol contents of the refined and bleached treated oil samples compared with the untreated oil.

\section{BIBLIOGRAPHY}

1. W. A. Pons Jr-- «Proceedings of Ninth Cottonseed Processing Clinc», Feb. 15-16. S.R.R.L., U.S.D.A., New Orleans, La. (1960).

2. A. S. El-Nockrashy, F. A. Zaher and F. Osman."Cottonseed colour fixed pigments I. Selectivity of hexan isomers".-Die Nahrung 20 (1976) 117.

3. F. Osman, F. A. Zaher and A. S. El-Nockrashy."Cottonseed colour - fixed pigments II. Role of hexane isomers on oil quality».-Die Nahrung 20 (1976) 475.

4. M. Attia, F. S. Taha, H. M. Mustafa and A. S. El-Nockrashy.«Bench scale treatment of colour fixed cottonseed oil».-Die Nahrung 32 (3) (1988) 281.

5. W. A. Pons Jr., J. C. Kuck and V. L. Frampton.-U.S. Patent «Bleaching off-colour cottonseed oils».- U.S. 3, 036, 102, May 22, 1962.

6. M. Atteia, M. Abbasy, A. S. El-Nockrashy and Z. E. Shoeb.- "Cottonseed colour - fixed pigments III. Prevention of colour fixation and removal of colour fixed pigments".-Die Nahrung 25 (1981) 608-615.

7. American Oil Chemists'Society, Official and Tentative Methods, $3^{\text {rd }}$ ed. Ed. By R. O. Walker, Chicago 1980.

8. C. H. Boatner, R. T. O'Connor, M. C. Curet and C. S. Samules. - «The pigments of cottonseed III. Gossyfulvin, a native cottonseed pigment related to gossypol».Journal American Oil Chemists'Society 24 (1947) 1268.

9. W. A. Pons Jr., J. C. Kuck and V. L. Frampton.- «Colour index for cottonseed oils".-Journal American Oil Chemists'Society 37 (1960) 671.

10. L. C. Beradi and V. L. Frampton.- «Note on gossypol and its relation to colour fixation in cottonseed oils.Journal American Oil Chemists'Society 34 (1957) 399401.

11. J. W. Ryder.- «Oil Mill Gazetter» 65 (1964) 10.

12. M. M Paulose and K. T. Achaya.- «Treating crude cottonseed oil to prevent colour fixation alternative to washing".-Indian Oilseeds J. 6 (1962) 171.

13. F. S. Taha, G. El-Dewany and A. S. El-Nockrashy."Treatment of crude colour fixed cottonseed oil».Seifen Ole Fette Wasche 113 (18) (1988) 680.

14. F. H. Thurber, H. L. E. Vix, W. A. Pons Jr., A. J. Crovetto and N.B. Knoepfler.- "The effect of processing conditions on the properties of screw-press cottonseed meal and oil».--Journal American Oil Chemists'Society 31 (1954) 348-388.

15. R. Adams, B. S. Friedman, C. C. Price, R. C. Morris and E. C. Kirk Patrick. - «Structure of gossypol. VI. Addition products with bütadienes". -Journal American Chemistry Society 60 (1938) 2160.

16. R. Adams and E. C. Kirk Patrick.- «Gossypol, its derivatives and of certain dinaphthalene compounds".Journal American Chemistry Society 60 (1938) 2174.

17. R. Adams, R. C. Morris, T. A. Geissman, D. J. Butterbaugh and E. C. Kirk Patrick.- «Gossypol. XV. Interpretation of its reactions".- Journal American Chemistry Society 60 (1938) 2197. 